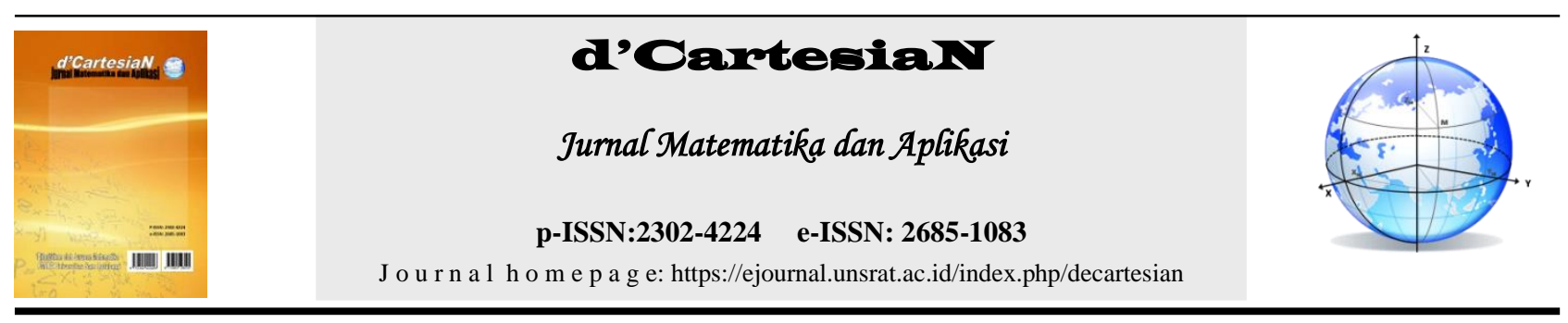

\title{
Lintasan Hamiltonian pada Graf 4-Connected
}

\author{
Roy A. M. Makalew ${ }^{1}$, Chriestie E. J. C. Montolalu1 ${ }^{*}$, Mans. L. Mananohas ${ }^{1}$ \\ ${ }^{1} J u r u s a n$ Matematika-Fakultas Matematika dan Ilmu Pengetahuan Alam-Universitas Sam Ratulangi Manado, Indonesia
}

*Corressponding author : chriestelly@unsrat.ac.id

\section{A B S T R A K}

Teori graf merupakan salah satu materi dalam ilmu Matematika yang digunakan dalam bentuk representasi masalah secara deskripsi. Menurut beberapa penelitian,teori graf banyak digunakan untuk menganalisa topik yang berkaitan dengan transpotasi, rangkaian jaringan komputer atau telepon, dan hal lainnya. Tujuan penelitian ini, yaitu untuk membuktikan bahwa penggunaan 4-connected graph yang dibentuk dari beberapa definisi graf telah didapatkan model graf 4-connected graph yang tidak Uniquely Hamiltonian.. Penelitian ini dilakukan dengan menggunakan sumber pustaka dan sumber jurnal terpercaya. Dengan batasan graf yang digunakan yaitu graf sederhana, graf terhubung dan graf Hamilton. Dari hasil dapat diketahui bahwa model graf $G$ yang di dapat ,yaitu graf lengkap $K_{5}$ memenuhi batasan graf dan definisi 4connected. Sehingga disimpulkan $K_{5}$ sebagai graf 4-connected bukanlah graf Uniquely Hamiltonian.

\section{A B S T R A C T}

Graph theory is one of the materials in Mathematics which is used in the form of a description of the problem. According to several studies, graph theory is widely used to analyze topics related to transportation, computer or telephone network circuits, and other things. The purpose of this research is to prove that the use of 4-connected graph which is formed from several graph definitions has obtained a 4-connected graph model which is not Uniquely Hamiltonian. This research was conducted using reliable library sources and journal sources. With the constraints of the graph used, namely simple graph, connected graph and Hamiltonian graph. From the results it can be seen that the graph model G obtained, namely the complete $\mathrm{K}_{5}$ graph meets the graph constraints and definition of 4-connected. So it can be concluded that $\mathrm{K}_{5}$ as a 4-connected graph is not a Uniquely Hamiltonian graph.

\section{INFO ARTIKEL:}

Diterima : 1 Agustus 2020

Diterima setelah revisi : 31 Agustus 2020

Tersedia online : 6 Januari 2020

\section{Kata Kunci:}

4-Connected

Uniquely Hamiltonian

\section{PENDAHULUAN}

Representasi masalah dapat dimodelkan dalam bentuk penulisan maupun penggambaran dan hal tersebut harus dipastikan dapat terselesaikan. Pokok pokok bahasan masalah tersebut sampai saat ini diselesaikan dengan berbagai terapan sesuai dengan terkaitnya bahasan yang akan diselesaikan. Graf salah satu terapan yang digunakan sampai saat ini dengan menggunakan teorinya. Masalah pertama kali yang menggunakan teori graf ini terjadi pada tahun 1736 . Masalah tersebut adalah masalah jembatan Koningsberg di kota Koningsberg (sebelah timur negara Prussia, Jerman), sekarang bernama kota Kaliningrad, dimana terdapat sungai Pregal yang mengalir mengitari pulau Kneiphof lalu bercabang menjadi dua buah anak sungai. Upaya penyelesaian masalah tersebut telah dilakukan oleh seorang matematikawan Swiss yang bernama L. Euler. Ia merupakan orang pertama yang berhasil menemukan jawaban dengan pembuktian sederhana dimodelkanya masalah ini kedalam graf. Daratan atau titik - titik yang dihubungkan oleh jembatan adalah titik yang di sebut simpul dan jembatan merupakan garisnya disebut juga sisi [7].

Teori graf sampai saat ini telah berkembang diberbagai penggunaan representasinya. Kebanyakan digunakan dalam permasalahan transportasi , ilmu komputer, rangkaian listrik dan lainnya. Terapan pemodelan ini dapat digunakan untuk mempermudah menganalisis suatu permasalahan dalam graf tersebut. Sampai saat ini graf mempunyai banyak jenis untuk dimodelkan. Graf terhubung (connected graph) , lintasan dan sirkuit Hamiltonian adalah salah satu penerapan yang sering digunakan dan dimodelkan dalam teori graf. Graf terhubung dikenal dengan suatu graf yang memiliki dua buah titik $u$ dan titik $v$ dikatakan terhubung jika terdapat garis dari $u$ ke $v$. Sedangkan sirkuit dan lintasan Hamiltonian adalah graf yang titik - titiknya dilalui graf tepat sekali [7].

Penelitian tentang graf terhubung telah berkembang, dimulai dari 1-connected graph , 2connected graph atau disebut juga dengan biconnected graph yang telah ditemukan oleh Merger dan 3- 
connected graph atau disebut juga dengan triconnected graph yang di temukan oleh Tutte, dan akhirnya didapatkan gabungan setiap bagiannya secara umum yaitu $k$-connected graph [2].

Penelitian teori graf lainnya yang dikaitkan dengan cycle telah diteliti oleh beberapa mahasiswa dan dosen F-MIPA di Universitas Sam Ratulangi Manado. Salah satu dosen yang membahas cycle yaitu Christie Montolalu mengenai pagenumber dari products $C_{m} \times C_{n}$ didasarkan oleh cycles. Masalah graf yang telah di bahas dalam penelitian ini ,diambil dari website 'Open Problem Garden' sebagai objek penelitian peneliti. Pokok bahasan tersebut yang menjadi dasar dari penelitian ini. Dalam penulisan ini, dibahas proses analisa pembuktiannya yang berupa 4connected graph tidak Uniquely Hamiltonian [3].

\section{TINJAUAN PUSTAKA}

\subsection{Definisi Graf \\ Definisi 1.}

Graf $G$ adalah pasangan himpunan simpul ( $V$ ) dan $\operatorname{sisi}(E)$ atau $(V, E)$, dimana notasinya $G=(V, E)[8]$.

Definisi 1 menyatakan bahwa $V$ tidak boleh kosong, sedangkan $E$ boleh kosong. Dalam hal ini $V$ adalah himpunan tidak kosong dari simpul-simpul (vertices atau nodes) dan $E$ adalah himpunan sisi (edges atau arcs) yang menghubungkan sepasang simpul. Jadi, sebuah graf dimungkinkan tidak mempunyai sisi satu buah pun, tetapi simpulnya harus ada, minimal satu. Graf yang hanya mempunyai satu buah simpul tanpa sebuah sisi pun dinamakan isolated vertex atau graf trivial. Simpul pada graf dapat dinomori dengan huruf, seperti $a, b, c, \ldots, v, w, \ldots$, dengan bilangan asli 1, 2, 3, ..., atau gabungan keduanya. Sedangkan sisi yang menghubungkan simpul $u$ dengan simpul $v$ dinyatakan dengan pasangan $(u, v)$ atau dinyatakan dengan lambang $e_{1}, e_{2}, \ldots$. Dengan kata lain, jika $e$ adalah sisi yang menghubungkan simpul $u$ dengan simpul $v$, maka $e$ dapat ditulis sebagai $e=(u, v)$ atau $e=u v$ [8].

\section{Definisi 2.}

Jumlah simpul dan jumlah sisi pada graf $G$ adalah kardinalitas graf, dimana jumlah simpul dinotasikan dengan $n=|V|$, sedangkan jumlah sisi dinotasikan dengan $m=|E|[7]$

Contoh definisi 2 dapat dilihat seperti pada Gambar 1, dimana graf $G_{1}$ mempunyai kardinalitas graf $n=4$ dan $m=5$ [8].

\subsection{Graf Sederhana dan Graf Tidak Sederhana}

\subsubsection{Graf sederhana (simple graph). Definisi 3.}

Graf sederhana $G$ adalah graf yang $\forall \operatorname{simpul}(V) \nexists$ sisi $(E)$ yaitu sisi gelang dan sisi ganda [1].

Misalkan graf sederhana direpresentasikan seperti pada Gambar 1 sebagai $G_{1}$ (contoh penerapan dalam bentuk jaringan telepon). Untuk simpul simpul 1,2,3 dan 4 berwarna biru menyatakan telepon, sedangkan sisi - sisi berwarna hitam menyatakan saluran telepon untuk berkomunikasi . Terlihat jelas bahwa setiap simpul yang terhubung oleh setiap sisi tidak memiliki sisi gelang dan sisi ganda [1].

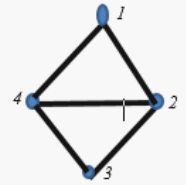

Gambar 1. $G_{1}$ sebagai Graf Sederhana

\subsubsection{Graf tidak sederhana (unsimple- graph).}

Definisi 4.

Graf tidak sederhana $G$ adalah graf yang $\forall$ simpul $(V), \exists$ sisi gelang atau sisi ganda maupun keduanya [11].

Dengan kata lain graf tidak sederhana $G=(V, E)$ terdiri dari himpunan tidak kosong simpul $(V)$ dan sisi (E) adalah himpunan-ganda (multiset) yang mengandung sisi ganda atau sisi gelang maupun keduanya. Ada dua macam graf tak sederhana, yaitu graf ganda (multigraph) dan graf semu (pseudograph). Graf ganda adalah graf yang mengandung sisi ganda. Sedangkan graf semu adalah graf yang mengandung sisi gelang (loop). Misalkan graf ganda direpresentasikan seperti pada Gambar 2 sebagai $G_{2}$. Untuk sisi - sisi ganda berwarna kuning yang menghubungkan sepasang simpul - simpul berwarna biru antara simpul 1 dan 2, dan antara simpul 2 dan 3 masing - masing terdapat sisi ganda. Sisi ganda jumlahnya dapat lebih dari dua buah dan dapat diasosiasikan sebagai pasangan tak-terurut yang sama [8].

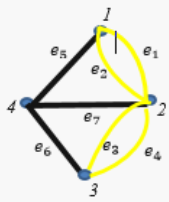

Gambar 2. $G_{2}$ sebagai Graf Ganda

Selanjutnya, misalkan graf semu direpresentasikan seperti pada Gambar 3 sebagai $G_{3}$. Untuk graf semu, gelangnya berwarna hijau terletak pada simpul 2. Graf semu lebih umum digunakan daripada graf ganda , karena keunikan sisi pada graf dapat terhubung simpul itu sendiri [8].

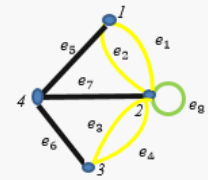

Gambar 3. $G_{3}$ sebagai Graf Semu

\subsection{Graf Tidak Berarah dan Berarah.}

\subsubsection{Graf tidak berarah (undirected graph)} Definisi 6.

Graf tidak berarah $G$ adalah graf yang sisinya sama $\operatorname{dimana}(u, v)=(v, u)[8]$.

Dengan kata lain sisinya tidak mempunyai orientasi arah dan urutan pasangan simpul yang dihubungkan oleh sisi tidak diperhatikan . Misalkan tiga buah graf direpresentasikan seperti pada Gambar 1, Gambar 2 dan Gambar 3 sebagai contoh graf takberarah. Untuk $G_{1}, G_{2}, G_{3}$ dapat dikatakan sebagai graf tidak berarah karena setiap sisi yang terhubung antara setiap simpul $(u, v)=(v, u)$ adalah sisi yang sama [8]. 


\subsubsection{Graf berarah (directed graph atau digraph) \\ Definisi 7.}

Graf berarah $G$ adalah graf yang sisinya tidak sama dan diberi arah dimana $(u, v) \neq(v, u)[8]$.

Misalkan graf berarah direpresentasikan seperti pada Gambar 4. Untuk sisi $(E)$ berwarna merah diberikan orientasi arah disebut juga busur (arc) dimana $(u, v)$ dan $(v, u)$ adalah dua buah unsur yang berbeda dan untuk simpul $u$ dinamakan simpul asal (initial vertex) dan simpul $v$ dinamakan simpul terminal (terminal vertex). Pada Gambar 4 dimisalkan simpul $u=1$ dan simpul $v=3$, maka $(u, v)=(1,3)$ sebagai sisi yang arahnya ke simpul 3 dan $(v, u)=(3,1)$ sebagai sisi yang arahnya ke simpul 1. Oleh karena itu, graf pada Gambar 4 disebut sebagai graf yang berarah dimana $(1,3) \neq(3,1)$. Graf berarah penerapannya sering dipakai dalam kehidupan sehari - hari untuk menggambarkan aliran proses, peta lalu lintas suatu kota (jalan searah atau dua arah), dan sebagainya [8].

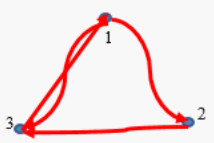

Gambar 4. $G_{4}$ sebagai Graf Berarah

\subsection{Graf Lengkap (Complete Graph)} Definisi 8.

Graf lengkap $G$ adalah graf yang $\forall \operatorname{simpul}(V), \exists$ sisi $(E)$ yang terhubung antara setiap dua simpul dan dinotasikan dengan $K_{n}$ [11].

Untuk graf lengkap $K_{n}$, dimisalkan $n$ sebagai jumlah simpul untuk setiap $n \in$ bilangan asli $N$. Misalkan graf lengkap direpresentasikan seperti pada Gambar 5. Untuk $K_{1}$ merupakan isolated vertex dimana jumlah simpulnya $=1$ atau $n=1$ dan tak memiliki sisi. Untuk $K_{2}$, memiliki 1 sisi dan jumlah simpulnya $=2$ atau $n=2$. Untuk $K_{3}$, memiliki jumlah simpul $=3$ atau $n=3$ dan sisinya $=3$. Untuk $K_{4}$, memiliki jumlah simpul $=4$ atau $n=4$ dan sisinya $=6$. Dan untuk $K_{5}$, memiliki jumlah simpul $=5$ atau $n=5$ dan sisinya $=10[11]$.

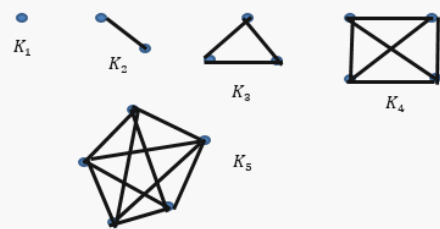

Gambar 5. Contoh Graf Lengkap $K_{n}$ dimana $n=$ $1,2,3,4,5$

\subsection{Jalan Lintasan (Walk), Lintasan (Path),} atau Sirkuit (Cycle).

\section{Definisi 9.}

Walk adalah barisan terbatas dari simpul - simpul $v_{0}, v_{1}, \ldots, v_{n-1}$ dan sisi - sisi $e_{1}, e_{2}, \ldots, e_{n}$ dari suatu graf $G$ $: v_{0}, e_{1}, v_{1}, e_{2}, \ldots, e_{n}, v_{n-1} \exists$ jalan lintasan didalamnya , dimana titik awalnya $v_{0}$ dan titik akhirnya $v_{n-1}[6]$.

Walk sederhana adalah jalan lintasan dimana tidak ada sisi yang berulang. Panjang dari walk adalah jumlah banyaknya sisi . Sebuah lintasan adalah suatu walk dimana tidak ada simpul yang berulang. Suatu walk dikatakan tertutup (closed) saat titik pertama dan terkahir $v_{0}$ dan $v_{n}$ adalah sama. Closed walk disebut juga cycle atau sirkuit. Misalkan graf untuk walk dan path direpresentasikan seperti pada Gambar 6 dimana simpul - simpulnya terdiri dari 8 huruf abjad $a, b, c, d, e, f, g$ dan $h$ yang berwarna biru. Untuk walk dapat dilihat jelas bahwa simpul $a$ sebagai simpul awal $a=v_{0}$ dan diakhiri dengan simpul $h=v_{n}$, dimana walk ini adalah lintasan karena tidak ada simpul yang berulang. Sama halnya juga dengan path dimana simpul $a$ sebagai simpul awal $a=v_{0}$ dan diakhiri dengan simpul $h=v_{n}$. Akan tetapi, panjang dari masing - masing keduanya berbeda yaitu 7 dan 4 yang dihitung didasarkan jumlah sisinya [11].

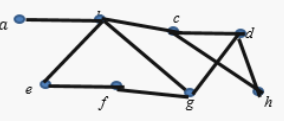

Gambar 6. Contoh Graf yang memiliki walk $(a, b, e, f, g, d, c, h)$ dan path $(a, b, g, d, h)$.

Teorema 1.

Suatu cycle dari panjang $n$ disebut sebagai sebuah walk tertutup dari panjang (length) $n$, untuk $n \geq$ 3 , dimana simpul - simpul $v_{0}, v_{1}, \ldots, v_{n-1}$ semuanya berbeda [11].

Bukti 1. (Berdasarkan definisi 8 dan 9 ).

Misalkan suatu graf $G$ dibentuk dari banyaknya simpul $V$ dari panjang $n$ ( $n$ vertices), untuk $n \in$ bilangan asli $N$ dan simpulnya saling terhubung antar simpul lainnya dengan banyaknya sisi $e$. Dengan digunakan definisi 8 yaitu definisi graf lengkap $K_{n}$ telah didapatkan bahwa untuk $n \geq 3$ pada suatu Graf $G$ pasti terdapat cycle. Dipilih $n=3$, berarti simpul - simpulnya $v_{0}, v_{1}, v_{2}$ dan sisi - sisinya $e_{1}, e_{2}, e_{3}$ dapat menjadi suatu walk tertutup (cycle) saat $v_{0}=v_{2}$ dengan lintasannya yaitu $v_{0}, e_{1}, v_{1}, e_{2}, v_{2}, e_{3}, v_{0}$ dimana membentuk suatu graf $G$ $=K_{3}$. Sehingga, graf $K_{3}$ dapat dikatakan juga sebagai walk tertutup (cycle).

$\therefore$ Jadi, terbukti benar pernyataan teorema 1 [11].

\subsection{Graf Terhubung (Connected Graph) \\ Definisi 10.}

Graf terhubung $G$ adalah graf tidak berarah $G$ jika $\forall$ pasang simpul $u$ dan $v$ dalam himpunan $V \exists$ lintasan dari $u$ ke $v$ dan jika tidak, maka $G$ disebut sebagai (disconnected graph) atau graf tidak - terhubung [11].

\section{Definisi 11.}

Cutpoint adalah penghilangan hanya satu saja simpul $v$ sebagai simpul potong dari suatu graf terhubung $G$ dan menjadi graf tidak terhubung yang menyisahkan beberapa komponen graf $G-v$ atau $G \mid v$ [11].

Misalkan cutpoint direpresentasikan seperti pada Gambar 7 dan Gambar 8. Untuk Gambar 8 dimisalkan sebagai graf terhubung yang telah di cutpoint dari Gambar 7 menjadi 2 buah komponen graf terpisah , sehingga didapatkan hasilnya seperti pada Gambar 8. Untuk hasil dari cutpoint adalah graf $G-f$ dimana simpul $f$ sebagai cutpoint dari graf tersebut [11].

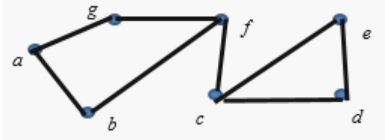

Gambar 7. Graf untuk cutpoint 

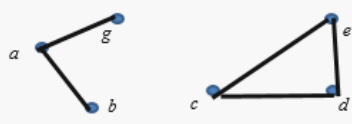

Gambar 8. Graf $G-f$ dengan jumlah komponennya 2

\section{Definisi 12.}

Cutedge adalah penghilangan hanya satu saja sisi $e$ sebagai sisisi potong dari suatu graf terhubung $G$ dan menjadi graf tidak terhubung yang menyisahkan beberapa komponen graf $G-e$ atau $G \mid e$ [11].

Misalkan cutedge direpresentasikan seperti pada Gambar 9 dan Gambar 10. Untuk Gambar 10 dimisalkan sebagai graf terhubung yang telah di cutedge dari Gambar 9 menjadi 2 buah komponen graf terpisah (memiliki isolated vertex), sehingga didapatkan hasilnya seperti pada Gambar 10. Untuk hasil dari cutedge adalah graf $G-b f$ dimana sisi $b f$ sebagai cutedge dari graf tersebut [11].

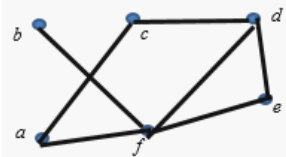

Gambar 9. Graf untuk cutedge

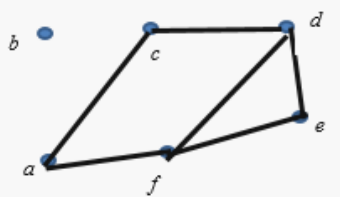

Gambar 10. Graf $b-f$ dengan jumlah komponennya 2

\subsection{Graf k-terhubung (k-Connected Graph)}

\section{Definisi 13.}

Cutset $(S)$ untuk simpul adalah jumlah minimal penghilangan simpul sebagai simpul potong dari suatu graf terhubung $G$ menjadi graf tidak terhubung yang menyisahkan beberapa komponen graf $G-S$ dimana dinotasikan dengan $\kappa(G)=\min \{|S| \mid S \leq V(G)\}=k$ dan $\kappa(G)$ disebut $k$-vertex connected [5].

\section{Definisi 14.}

Cutset $(S)$ untuk sisi adalah jumlah minimal penghilangan sisi sebagai sisi potong dari suatu graf terhubung $G$ menjadi graf tidak terhubung menyisahkan beberapa komponen graf $G-S$ dimana dinotasikan dengan $\kappa^{\prime}(G)=\min \{|S| \mid S \leq E(G)\}=k$ dan $\kappa^{\prime}(G)$ disebut $k$-edge connected [4].

\section{Definisi 15.}

Graf k-terhubung adalah jumlah minimal penghilangan dari gabungan kedua cutset simpul dan sisi sebagai simpul dan titik potong dari suatu graf terhubung $G$ y menjadi graf tidak terhubung yang menyisahkan beberapa komponen graf $G-S$ dimana $\kappa(G)=\kappa^{\prime}(G)=k$ disebut sebagai $k$-connected graph [11].

Misalkan graf $\mathrm{k}$ - terhubung direpresentasikan seperti pada Gambar 11, Gambar 12 dan Gambar 13 . Untuk $\kappa(G)=1$ didapatkan dari jumlah minimal penghilangan simpul atau cutset simpul, dimana simpulnya adalah simpul $a$. Sehingga, hasilnya dapat dilihat seperti pada Gambar 12. Sedangkan untuk $\kappa^{\prime}(G)=2$ didapatkan dari jumlah minimal penghilangan sisi atau cutset sisi, dimana misalkan dipilih sisinya adalah sisi $a b$ dan $a e$. Sehingga, hasilnya dapat dilihat seperti pada Gambar 13 [9].

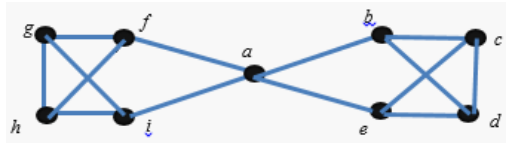

Gambar 11. Graf $G$ dengan $(G)=1, \kappa^{\prime}(G)=2$
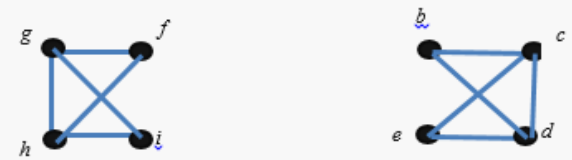

Gambar 12. Graf $G$ yang di cutset simpul dimana
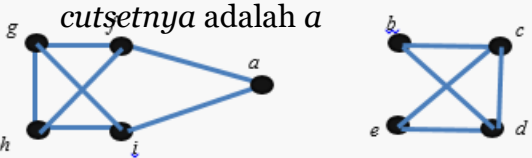

Gambar 13. Graf $G$ yang di cutset sisi dimana cutsetnya adalah $a b$ dan $a e$

Teorema 2.

$K_{n}$ (complete graph) adalah $(n-1)$ vertex connected [12].

Bukti 2. (Berdasarkan definisi 8 dan 13)

Diketahui :

1. Graf lengkap $K_{n}$ adalah graf sederhana dan terhubung.

2. $n$ adalah banyaknya simpul dari $K_{n}$, untuk $n \in N$.

3. $\quad k=n-1$, dimana $k$ adalah minimal cutset simpul dari $k$-vertex connected $(\kappa(G))$.

Dipilih $n=5$, karena $K_{5}$ adalah complete graph. Maka, diperoleh graf :

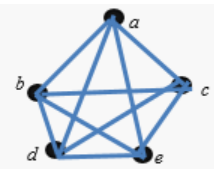

Gambar 14. Graf $K_{5}$

Oleh karena itu, berdasarkan definisi 13 untuk graf $K_{5}$ diperoleh jumlah cutsetnya $|S|=5$, dimana $S=$ $\{a, b, c, d\},\{a, c, d, e\},\{a, b, d, e\},\{a, b, c, e\},\{b, c, d, e\}$ adalah cutset dari $K_{5}$. Sehingga, jumlah minimal $\kappa(G)$ berdasarkan cutset simpul dari graf lengkap $K_{5}$ adalah $\kappa(G)=4$. Karena $k=n-1=\kappa(G)=4$, terbukti bahwa $K_{5}$ adalah (5-1)-vertex connected atau ditulis 4-vertex connected.

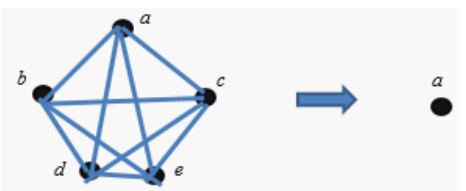

Gambar 15. Graf $K_{5}$ saat cutset simpulnya $\{b, c, d, e\}$ untuk $\kappa(G)=4$

$\therefore$ Jadi, $K_{5}$ adalah 4-vertex connected graph [12].

\subsection{Graf Hamilton (Hamiltonian) \\ Definisi 16.}

Lintasan Hamilton adalah lintasan (path) $\forall$ simpul $(V)$ dilalui dalam graf $G$ tepat hanya satu kali , dimana simpul asal $v_{0} \neq \operatorname{simpul}$ akhir $v_{n}[11]$.

\section{Definisi 17.}


Lintasan tertutup Hamilton (Hamilton cycle) adalah lintasan (path) $\forall$ simpul ( $V$ ) dilalui dalam graf $G$ tepat hanya satu kali kecuali untuk simpul asal dan simpul akhir, dimana simpul asal $v_{0}=$ simpul akhir $v_{n}[11]$.

Graf yang memiliki cycle Hamilton dinamakan graf Hamiltonian, sedangkan graf yang hanya memiliki lintasan Hamilton disebut graf semiHamiltonian. Misalkan graf Hamilton direpresentasikan seperti pada Gambar 16, Gambar 17, dan Gambar 18. Untuk Gambar 16 memiliki lintasan Hamilton dimana simpul awalnya $v_{0}=3$ dan simpul akhirnya $v_{n}=4$ dengan jalurnya yaitu 3, 2, 1, 4. Untuk Gambar 17 memiliki lintasan dengan salah satu jalurnya yaitu 1, 4, 2 tapi bukanlah lintasan Hamilton. Dikarenakan lintasan pada Gambar 17 tidak memuat semua simpul sebagai jalurnya. Sehingga jelas bahwa Gambar 17 tidak memiliki lintasan Hamilton dan juga Hamilton cycle. Sedangkan ntuk Gambar 18 memiliki Hamilton cycle dimana simpul awal dan akhirnya sama $v_{0}=v_{n}=1$ dengan jalur lintasannya yaitu $1,2,3$, $4,1[11]$.

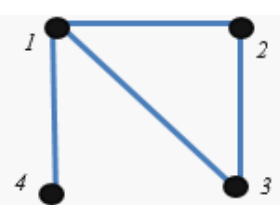

Gambar 16. Graf yang memiliki lintasan Hamilton $(3,2,1,4)$

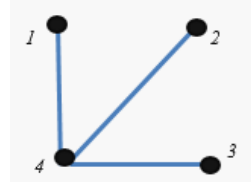

Gambar 17. Graf yang tidak memiliki Lintasan Hamilton dan Hamilton cycle

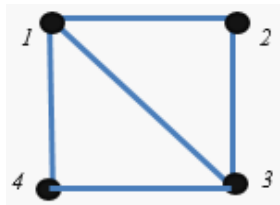

Gambar 18. Graf yang memiliki Hamilton cycle $(1,2,3,4,1)$

Definisi 18.

Graf Uniquely Hamiltonian adalah graf yang memiliki Hamilton cycle dan tepat hanya satu Hamilton cycle saja [4].

Misalkan graf Uniquely Hamiltonian direpresentasikan seperti pada Gambar 19 sebagai graf yang memiliki Hamilton cycle. Untuk Gambar 19 memiliki Hamilton cycle dimana jalur lintasan tertutupnya sama yaitu $a, b, c, d, a=b, c, d, a, b=c, d$, $a, b, c=d, a, b, c, d$. Sehingga, disimpulkan bahwa graf Gambar 19 hanya memiliki 1 Hamilton cycle [4].

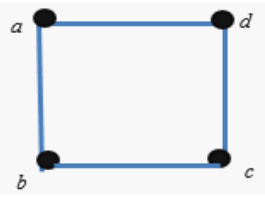

Gambar 19. Graf yang hanya memiliki 1 Hamilton cycle

\section{Teorema 3.}

$K_{n}$ dengan $n$ vertices dimana $n \geq 3$, mempunyai

Hamiltonian cycles sebanyak $\frac{1}{2}(n-1)$ [10].

Bukti 3. (Berdasarkan definisi 8 dan 17)
Misalkan suatu graf $K_{n}$ dengan $n$ vertices dimana $n \leq 2$. Pilih $n=2$, maka graf tersebut adalah graf $K_{2}$. Sehingga ,berdasarkan Gambar 5 tersebut hanya berupa lintasan Hamilton dan tidak terdapat cycle Hamilton. Jika dipilih $n=3$, maka graf tersebut adalah graf $K_{3}$. Sehingga, berdasarkan Gambar 5 tersebut ada suatu cycle Hamilton. Oleh karena itu, untuk $n \geq 3$, didapatkan bahwa :

$$
\frac{1}{2}(n-1)=\frac{1}{2}(3-1) \geq 1
$$

$\therefore$ Jadi, terbukti benar pernyataan teorema 3 [10].

\section{METODOLOGI PENELITIAN}

\subsection{Waktu dan Tempat Penelitian}

Penelitian telah dilaksanakan selama bulan Maret 2018 sampai bulan April 2020 dengan tempat penelitian di jurusan Matematika, fakultas Matematika dan Ilmu Pengetahuan Alam universitas Sam Ratulangi Manado.

\subsection{Metode Penelitian}

Metode yang digunakan adalah metode studi pustaka. Pada awalnya penulis mengumpulkan referensi-referensi berupa buku, jurnal maupun sumber lainnya seperti internet. Selanjutnya dilakukan tahapan penelitian dengan meneliti dan menggabungkan referensi - referensi yang diacu sesuai dengan tujuan penelitian.

\subsection{Langkah - langkah Penelitian}

1. Dipilih model suatu graf $G$ adalah graf sederhana.

2. Didefinisikan model suatu graf $G$ sesuai definisi connected graph.

3. Didefinisikan model suatu graf $G$ sesuai definisi $k$-connected graph dimana $k=4$.

4. Didefinisikan model suatu graf $G$ sesuai definisi cycle Hamiltonian.

5. Dibuktikan model suatu graf $G$ sesuai teorema teorema.

6. Didapatkan model suatu graf $G$ adalah graf $G$ (4connected graph) .

7. Dibuktikan graf $G$ (4-connected graph) memenuhi definisi Uniquely Hamilton atau tidak.

\section{HASIL DAN PEMBAHASAN}

\subsection{Menentukan Model Graf $G$}

Tahap pertama dalam menentukan model graf $G$ adalah graf tersebut telah dibatasi sesuai definisi beberapa graf yaitu graf sederhana (simple graph), graf terhubung (connected graph), dan graf Hamilton (Hamiltonian). Pemilihan batasan graf ini untuk memudahkan penentuan model graf $G$ yang diinginkan penelti sesuai rumusan masalah yang diteliti. Model suatu graf yang dibentuk harus memenuhi ketiga graf tersebut. Tahap kedua dalam menentukan model graf $G$ adalah graf yang diinginkan haruslah berbentuk graf $k$-connected. Model graf $G$ yang sudah dibentuk ke graf $k$-connected haruslah dipilih $k=4$ agar menjadi graf yang diinginkan yaitu graf 4-connected.

Untuk tahap pertama direpresentasikan seperti pada Gambar 20, Gambar 21, Gambar 22 , Gambar 24 dan Gambar 26 . Misalkan $n$ adalah jumlah simpul $V$ pada suatu graf $G$. Saat $n=1$, maka graf yang dibentuk dapat dilihat seperti pada Gambar 20 berupa graf isolated vertex atau graf lengkap $K_{1}$ dimana $v_{0}$ sebagai simpulnya. Graf $K_{1}$ memenuhi definisi graf sederhana 
Roy A. M. Makalew, Chriestie E. J. C. Montolalu, Mans L. Mananohas

d'Cartesian: Jurnal Matematika dan Aplikasi, Vol. 9, No. 2, (September 2020): 181-188

(definisi 1), tetapi tidak memenuhi definisi kedua graf yang lain yaitu graf terhubung ( $K_{1}$ bukanlah graf terhubung ) dan graf Hamilton ( $K_{1}$ juga bukanlah graf Hamilton). Oleh karena itu, graf ini bukanlah model graf $G$ yang diinginkan.

$$
v_{0}
$$

Gambar 20. Graf isolated vertex $=K_{1}$

Saat $n=2$, maka graf yang dibentuk dapat dilihat seperti pada Gambar 21 berupa graf lengkap $K_{2}$ dimana $v_{0}$ dan $v_{1}$ sebagai simpulnya yang dihubungkan dengan sisinya yaitu $e_{1}$. Graf $K_{2}$ memenuhi definisi graf sederhana (definisi 1), dan memenuhi definisi graf terhubung (definisi 10) tetapi tidak memenuhi definisi graf Hamilton ( $K_{2}$ bukanlah graf Hamilton).

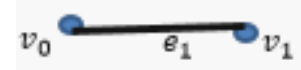

Gambar 21. Graf $K_{2}$

Saat $n=3$, maka graf yang dibentuk dapat dilihat seperti pada Gambar 22 berupa graf $K_{3}$ dimana $v_{0}, v_{1}, v_{2}$ sebagai simpulnya dan $e_{1}, e_{2}, e_{3}$ sebagai sisinya. Graf $K_{3}$ memenuhi definisi graf sederhana (definisi 1), graf terhubung (definisi 10), dan definisi graf Hamilton (definisi 17). Dikarenakan memenuhi tahap pertama, maka dilanjutkan ke tahap kedua. Untuk tahap kedua direpresentasikan seperti pada Gambar 23, Gambar 25 dan Gambar 27. Graf $K_{3}$ yang sudah memenuhi ketiga definisi graf tersebut memenuhi juga definisi graf $k$-connected (definisi 15) . Graf $K_{3}$ sebagai graf 2-connected dapat dilihat jelas pada Gambar 23 didapatkan dari definisi 15.

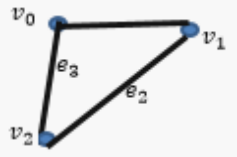

Gambar 22 . Graf $K_{3}$

Untuk panah berwarna kuning ditunjukkan sebagai $\kappa(G)$ hasil dari salah satu cutset simpul yaitu $\left(v_{1}, v_{2}\right)$ terhadap minimal jumlah simpul yang dihilangkan yaitu simpul $v_{1}$ dan simpul $v_{2}$, sehingga didapatkan komponen grafnya berupa graf isolated vertex atau graf $K_{1}$ dimana $v_{0}$ sebagai simpulnya. Selain cutset simpul $\left(v_{1}, v_{2}\right)$ seperti pada Gambar 23, cutset simpul yang didapatkan juga yaitu $S=$ $\left\{\left(v_{0}, v_{1}\right),\left(v_{1}, v_{2}\right),\left(v_{0}, v_{2}\right)\right\}$. Oleh karena itu $\kappa(G)$ yang didapatkan dari cutset simpul - simpul tersebut adalah $\kappa(G)=2$.

Sedangkan untuk panah berwarna hijau ditunjukkan sebagai $\kappa^{\prime}(G)$ hasil dari cutset sisi $\left(e_{1}, e_{3}\right)$ terhadap minimal jumlah sisi yang dihilangkan yaitu sisi $e_{1}$ dan sisi $e_{3}$, sehingga didapatkan komponen grafnya berupa graf isolated vertex atau graf $K_{1}$ dimana $v_{0}$ sebagai simpulnya dan graf $K_{2}$ terdiri dari simpul $v_{1}$ dan simpul $v_{2}$ dengan $e_{2}$ sebagai sisinya. Selain cutset sisi $\left(e_{1}, e_{3}\right)$ seperti pada Gambar 2 adapun cutset sisi yang telah didapatkan juga yaitu $S=$ $\left\{\left(e_{1}, e_{2}\right),\left(e_{1}, e_{3}\right),\left(e_{2}, e_{3}\right)\right\}$. Oleh karena itu, $\kappa^{\prime}(G)$ yang didapatkan dari cutset sisi - sisi tersebut adalah $\kappa^{\prime}(G)$ = 2. Dikarenakan $\kappa(G)=\kappa^{\prime}(G)=2$, maka graf $K_{3}$ disebut sebagai graf 2-connected. Hasilnya karena graf $K_{3}$ disebut sebagai graf 2-connected, berarti graf $K_{3}$ bukanlah model graf yang diinginkan.

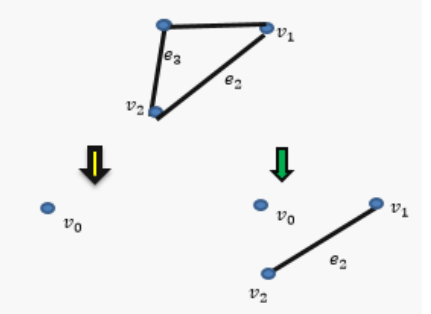

Gambar 23. Graf $K_{3}$ sebagai graf 2-connected

Kembali lagi ke tahap pertama saat $n=4$, maka graf yang dibentuk dapat dilihat seperti pada Gambar 24 berupa graf $K_{4}$ dimana $v_{0}, v_{1}, v_{2}, v_{3}$ sebagai simpulnya dan $e_{1}, e_{2}, e_{3}, e_{4}, e_{5}, e_{6}$ sebagai sisinya. Graf $K_{4}$ memenuhi definisi graf sederhana (definisi 1), graf terhubung (definisi 10), dan definisi graf Hamilton (definisi 17). Dikarenakan memenuhi tahap pertama, maka dilanjutkan ke tahap kedua. Graf $K_{4}$ sebagai graf 3-connected dapat dilihat jelas pada Gambar 25 didapatkan dari definisi 15 .

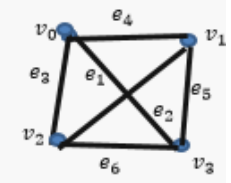

Gambar 24. Graf $K_{4}$

Untuk panah berwarna kuning ditunjukkan sebagai $\kappa(G)$ hasil dari salah satu cutset simpul yaitu $\left(v_{1}, v_{2}, v_{3}\right)$ terhadap minimal jumlah simpul yang dihilangkan yaitu simpul $v_{1}, v_{2}$ dan simpul $v_{3}$, sehingga didapatkan komponen grafnya berupa graf isolated vertex atau graf $K_{1}$ dimana $v_{0}$ sebagai simpulnya. Selain cutset simpul $\left(v_{1}, v_{2}, v_{3}\right)$ seperti pada Gambar 25, adapun cutset simpul yang didapatkan juga yaitu $S$ = $\left\{\left(v_{0}, v_{1}, v_{2}\right),\left(v_{0}, v_{1}, v_{3}\right),\left(v_{1}, v_{2}, v_{3}\right),\left(v_{0}, v_{2}, v_{3}\right)\right\} . \quad$ Oleh karena itu $\kappa(G)$ yang didapatkan dari cutset simpul simpul tersebut adalah $\kappa(G)=3$.

Sedangkan untuk panah berwarna hijau ditunjukkan sebagai $\kappa^{\prime}(G)$ hasil dari cutset sisi $\left(e_{2}, e_{3}, e_{4}\right)$ terhadap minimal jumlah sisi yang dihilangkan yaitu sisi $e_{2}, e_{3}$ dan sisi $e_{4}$, sehingga didapatkan komponen grafnya berupa graf isolated vertex atau graf $K_{1}$ dimana $v_{0}$ sebagai simpulnya dan graf $K_{3}$ terdiri dari simpul $v_{1}, v_{2}$ dan simpul $v_{3}$ dengan $e_{1}, e_{5}, e_{6}$ sebagai sisinya. Selain cutset sisi $\left(e_{2}, e_{3}, e_{4}\right)$ seperti pada Gambar 25, adapun cutset sisi yang di dapatkan juga untuk $n=4$ yaitu $S=$ $\left\{\left(e_{3}, e_{4}, e_{1}\right),\left(e_{1}, e_{5}, e_{4}\right),\left(e_{2}, e_{6}, e_{5}\right),\left(e_{1}, e_{3}, e_{6}\right)\right\} . \quad$ Oleh karena itu, $\kappa^{\prime}(G)$ yang didapatkan dari cutset sisi - sisi tersebut adalah $\kappa^{\prime}(G)=3$. Dikarenakan $\kappa(G)=\kappa^{\prime}(G)=$ 3 , maka graf $K_{4}$ disebut sebagai graf 3 -connected. Hasilnya karena graf $K_{4}$ disebut sebagai graf $3^{-}$ connected, berarti graf $K_{4}$ bukanlah model yang diinginkan.

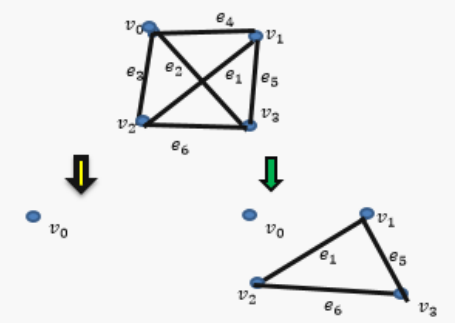

Gambar 25. Graf $K_{4}$ sebagai graf 3-connected 
Saat $n=5$, maka graf yang dibentuk dapat dilihat seperti pada Gambar 26 berupa graf $K_{5}$ dimana $v_{0}, v_{1}, v_{2}, v_{3}, v_{4}$ sebagai simpulnya dan $e_{1}, e_{2}, e_{3}, e_{4}, e_{5}, e_{6}, e_{7}, e_{8}, e_{9}, e_{10}$ sebagai sisinya. Graf $K_{5}$ memenuhi definisi graf sederhana (definisi 1), graf terhubung (definisi 10), dan definisi graf Hamilton (definisi 17). Dikarenakan memenuhi tahap pertama, maka dilanjutkan ke tahap kedua. Graf $K_{5}$ sebagai graf 4-connected dapat dilihat jelas pada Gambar 27 didapatkan dari definisi 15

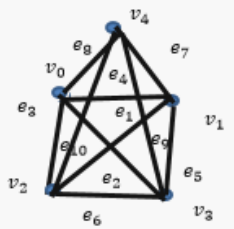

Gambar 26. Graf $K_{5}$

Untuk panah berwarna kuning ditunjukkan sebagai $\kappa(G)$ hasil dari salah satu cutset simpul yaitu $\left(v_{1}, v_{2}, v_{3}, v_{4}\right)$ terhadap minimal jumlah simpul yang dihilangkan yaitu simpul $v_{1}, v_{2}, v_{3}$ dan simpul $v_{4}$, sehingga didapatkan komponen grafnya berupa graf isolated vertex atau graf $K_{1}$ dimana $v_{0}$ sebagai simpulnya. Adapun cutset simpul - simpul lainnya didapatkan seperti pada Gambar 27, yaitu $S=$ $\left\{\left(v_{0}, v_{1}, v_{2}, v_{3}\right),\left(v_{0}, v_{1}, v_{2}, v_{4}\right),\left(v_{0}, v_{1}, v_{3}, v_{4}\right),\left(v_{1}, v_{2}, v_{3}, v_{4}\right)\right.$ ,$\left.\left(v_{0}, v_{2}, v_{3}, v_{4}\right)\right\}$. Oleh karena itu $\kappa(G)$ yang didapatkan dari cutset simpul - simpul tersebut adalah $\kappa(G)=4$.

Sedangkan untuk panah berwarna hijau ditunjukkan sebagai $\kappa^{\prime}(G)$ hasil dari cutset sisi $\left(e_{2}, e_{3}, e_{4}, e_{8}\right)$ terhadap minimal jumlah sisi yang dihilangkan yaitu sisi $e_{2}, e_{3}, e_{4}$ dan sisi $e_{8}$, sehingga didapatkan komponen grafnya berupa graf isolated vertex atau graf $K_{1}$ dimana $v_{0}$ sebagai simpulnya dan graf $K_{4}$ terdiri dari simpul $v_{1}, v_{2}, v_{3}$ dan simpul $v_{4}$ dengan $e_{1}, e_{5}, e_{6}, e_{7}, e_{9}, e_{10}$ sebagai sisinya. Selain cutset sisi $\left(e_{2}, e_{3}, e_{4}, e_{8}\right)$ seperti pada Gambar 27, adapun cutset sisi- sisi yang lainnya berupa $S=$ $\left\{\left(e_{3}, e_{4}, e_{1}, e_{8}\right),\left(e_{1}, e_{5}, e_{4}, e_{7}\right),\left(e_{2}, e_{6}, e_{5}, e_{9}\right),\left(e_{1}, e_{3}, e_{6}, e_{10}\right)\right.$ ,$\left.\left(e_{7}, e_{8}, e_{9}, e_{10}\right)\right\}$.

Oleh karena itu, $\kappa^{\prime}(G)$ yang didapatkan dari cutset sisi tersebut adalah $\kappa^{\prime}(G)=4$. Dikarenakan $\kappa(G)=$ $\kappa^{\prime}(G)=4$, maka graf $K_{5}$ disebut sebagai graf $4^{-}$ connected. Hasilnya karena graf $K_{5}$ disebut sebagai graf 4-connected, berarti graf $K_{5}$ adalah model yang diinginkan dan dipilih sebagai pembuktian tujuan penelitian.
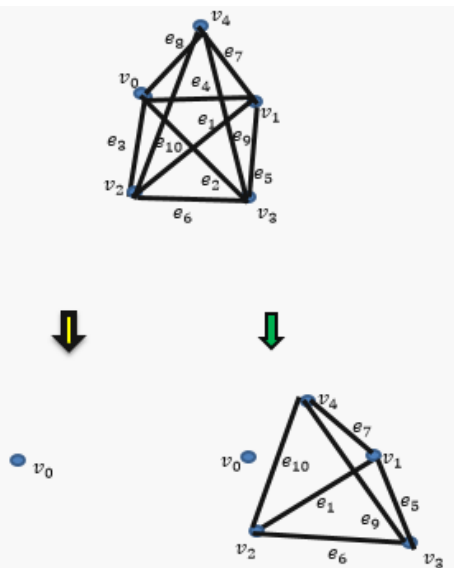

Gambar 27. Graf $K_{5}$ sebagai graf 4-connected
$K_{5}$ dengan Graf Uniquely Hamiltonian.

Setelah menentukan model graf $G$, dimana grafnya adalah $K_{5}$. Tahap selanjutnya adalah membuktikan kaitan graf 4-connected dengan graf Uniquely Hamiltonian . Berdasarkan definisi Uniquely Hamiltonian (definisi 18), dapat dilihat bahwa graf $K_{5}$ yang telah didefinisi sebagai graf Hamilton pasti memiliki Hamilton cycle). Maka, dikemukakan sebuah konjektur baru dari 'Open Problem Garden' untuk membuktikan kaitan kedua graf tersebut.

\section{Konjektur.}

Setiap 4-connected graph dengan sebuah Hamiltonian cycle memiliki Hamiltonian cycle kedua. (Dengan membuktikan adanya Hamiltonian cycle kedua, akan terbantah graf tersebut bukan Uniquely Hamiltonian ).

Bukti 4.

Dengan menggunakan teorema 3 , dipilih $n=5$ maka grafnya adalah $K_{5}$. Akibatnya, $K_{5}$ memiliki cycle Hamiltonian. Terlihat jelas bahwa :

$$
\frac{1}{2}(n-1)=\frac{1}{2}(5-1)=2
$$

Karena graf 4-connected graph $K_{5}$ jumlah cycle Hamiltonian adalah 2. Terbukti bahwa graf 4connected graph $K_{5}$ bukanlah graf Uniquely Hamiltonian.

$\therefore$ Jadi, terbukti pernyataan konjektur tersebut.

\section{PENUTUP}

\subsection{Kesimpulan}

Hasilnya yang didapatkan didasarkan pembuktiannya yaitu model graf $G$ untuk 4-connected adalah $K_{5}$ dimana graf 4-connected $K_{5}$ bukanlah graf Uniquely Hamiltonian .

\subsection{Saran}

Untuk penelitian selanjutnya , dapat menggunakan batasan graf yang lainnya atau memilih nilai $k \geq 5$ dari graf $k$-connected.

\section{REFERENSI}

[1] Adiwijaya. 2016. Matematika Diskrit dan Aplikasinya. Penerbit Alfabeta, Bandung.

[2] Cranston, W. D dan O, Suil. 2012. Hamiltonicity in Connected Reqular Graphs. Journal of Graph Theory. (113) : $22-24$

[3] Devos, M., and Samal, R. 2006 .CSI of Charles University.http://www.openproblemgarden.org/[ 20 Maret 2018].

[4] Johnson, T dan Thomas, R. 2002. Generating Internally Four-Connected Graphs. Jounal of Combinatorial Theory. (85): $21-58$.

[5] M, Kriesell. 2002. A Survey On Contractible Edges In Graphs of A Prescribed Vertex Connectivity. Graphs and Combinatorics. 18(1): 1 - 30.

[6] Montolalu, C. 2007. Pagenumber of Products $C_{m} \times C_{n}$ of Cycles [skripsi]. FMIPA UNSRAT, Manado.

\subsection{Analisis kaitan Graf 4-Connected}


Roy A. M. Makalew, Chriestie E. J. C. Montolalu, Mans L. Mananohas

d'Cartesian: Jurnal Matematika dan Aplikasi, Vol. 9, No. 2, (September 2020): 181-188

[7] Munir, R. 2014. Matematika Diskrit Edisi 5 . Penerbit Informatika, Bandung.

[8] Munir, R. 2016. Matematika Diskrit Edisi 6. Penerbit Informatika, Bandung.

[9] Schmidt, J. 2010. Strucutre and Constructions of 3-connected Graphs. Freie University, Berlin.

[10] Siang, J. Jek. 2009. Matematika Diskrit dan Aplikasinya pada Ilmu Komputer.Penerbit Andi, Yogyakarta.

[11] Walis,W . D .2007 . A Beginner's Guide to Graph Theory. Birkhauser, Boston.

[12]Wang,T., Zhang,Y., Chin,F., Ting,Hing-Fung., Tsin,Y., and Poon,Sheng-Hung. 2015. A Simple Algortihm for Finding All $k$-Edge-c onnected Components. Journal Plus One .10(9): 1- 9.

Roy A. M .Makalew (oicorgi95@gmail.com)

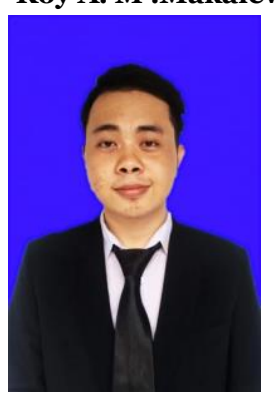

Lahir di Manado, Sulawesi

Utara pada tanggal 25 Nopember 1996. Menempuh pendidikan tinggi Jurusan Matematika, FMIPA, Universitas Sam Ratulangi Manado. Tahun 2020 adalah tahun terakhir ia menempuh studi. Makalah ini merupakan hasil penelitian skripsinya yang dipublikasikan.

Chriestie E. J. C. Montolalu (chriestelly@unsrat.ac.id) Lahir di Tomohon, pada tanggal 10 Desember 1985. Pada tahun 2007 mendapatkan gelar Sarjana Sains (S.Si) yang diperoleh dari Universitas Sam Ratulangi Manado. Gelar Master Of Science (M.Sc) diperoleh dari Universitas Of Queensland Australia pada tahun 2015. Ia bekerja di UNSRAT di Program Studi Matematika sebagai pengajar akademik tetap UNSRAT.

Mans L. Mananohas (mansmananohas@unsrat.ac.id)

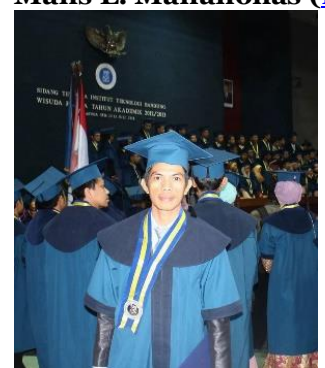
Lahir di Sangihe, 11 Juni 1984. Pada tahun 2013 memperoleh gelar Magister Sains (M.Si) dari Institut Teknologi Bandung. Menjadi pengajar tetap di Jurusan Matematika, Fakultas Matematika dan Ilmu Pengetahuan Alam Universitas Sam Ratulangi Manado. 